\title{
$1 \quad$ Ready for Impact? A validity and feasibility study of instrumented mouthguards (iMGs)
}

2

3 Ben Jones ${ }^{1,2,3,4,5}$, James Tooby ${ }^{1}$, Dan Weaving ${ }^{1}$, Kevin Till ${ }^{1,5}$, Cameron Owen ${ }^{1,4}$, Mark Begonia ${ }^{6}$, $4 \quad$ Keith Stokes ${ }^{7,8}$, Steve Rowson ${ }^{6}$, Gemma Phillips ${ }^{1,4,9}$, Sharief Hendricks ${ }^{1,2}$, Éanna Falvey ${ }^{10,11}$,

\section{Australia}

$13 \quad{ }^{4}$ England Performance Unit, Rugby Football League, Red Hall, Leeds, United Kingdom

$14{ }^{5}$ Leeds Rhinos Rugby League Club, Leeds, United Kingdom

$15{ }^{6}$ Biomedical Engineering and Mechanics, Virginia Tech, Blacksburg, VA, USA.

$16{ }^{7}$ University of Bath, Bath, United Kingdom

$17{ }^{8}$ Rugby Football Union, Twickenham, United Kingdom

189 Hull Kingston Rovers, Hull, United Kingdom

1910 World Rugby, 8,10 Pembroke St., Dublin, Ireland

2011 College of Medicine \& Health, University College Cork, Cork, Ireland

12 Sport and Exercise Sciences Research Institute, Ulster University, Belfast, United Kingdom

23 Corresponding author;

24 Prof. Ben Jones

25 Carnegie Applied Rugby Research (CARR) Centre,

26 Carnegie School of Sport,

27 Leeds Beckett University,

28 Leeds,

29 United Kingdom

30 b.jones@leedsbeckett.ac.uk 
ABSTRACT

Objectives Determine the validity and feasibility of current Instrumented mouthguards (iMGs) and associated systems.

Methods Phase 1; Four iMG systems (Football Research Inc [FRI], HitlQ, ORB, Prevent) were compared against dummy headform laboratory criterion standards (25, 50, 75, $100 \mathrm{~g})$. Phase 2; Four iMG systems were evaluated for on-field validity of iMG-triggered events against videoverification to determine true-positives, false-positives and false-negatives ( $20 \pm 9$ player matches per iMG). Phase 3; Four iMG systems were evaluated by eighteen rugby players, for perceptions of fit, comfort and function. Phase 4; Three iMG systems (FRI, HitlQ, Prevent) were evaluated for practical feasibility (system usability scale; SUS) by four practitioners.

44 Results Phase 1; Total concordance correlation coefficient was 98.3\%, 95.3\%, 42.5\% and 97.9\% for FRI, HitlQ, ORB and Prevent. Phase 2; Different on-field kinematics were observed between iMGs. Positive predictive values were $0.98,0.90,0.53$ and 0.94 for FRI, HitIQ, ORB and Prevent. Sensitivity values were $0.51,0.40,0.71$ and 0.75 for FRI, HitlQ, ORB and Prevent. Phase 3; player perceptions of fit, comfort and function were 77\%, 6/10, 55\% for $\mathrm{FRI}, 88 \%, 8 / 10,61 \%$ for HitlQ, $65 \%, 5 / 10,43 \%$ for ORB, and 85\%, 8/10, 67\% for Prevent. Phase 4; SUS was 51.3-50.6/100, 71.3-78.8/100, and 83.8-80.0/100 for FRI, HitIQ, and Prevent.

51 Conclusion This study shows that differences between current iMG systems exist. Sporting 52 organisations can use these findings to ensure accurate head acceleration event data are 53 obtained and system adoption is optimized, to support player welfare initiatives directly related to 54 long-term brain health. 
medRxiv preprint doi: https://doi.org/10.1101/2022.01.28.22270039; this version posted January 30, 2022. The copyright holder for this preprint (which was not certified by peer review) is the author/funder, who has granted medRxiv a license to display the preprint in perpetuity.

All rights reserved. No reuse allowed without permission.

\section{Ready for Impact? A validity and feasibility study of instrumented mouthguards (iMGs)}

\section{INTRODUCTION}

Instrumented mouthguards (iMGs) have potential to quantify head acceleration events (HAEs) in sport. HAEs can occur due to direct impacts to the head or inertial head loading from impacts to the body. iMGs can provide data to quantify the cumulative HAE experienced by players and also establish the biomechanical mechanisms of injury for concussion, which are a concern for sports.[1] Limited validation and feasibility studies exist that evaluate iMGs and their associated systems,[2,3] thus their appropriateness for both research and practice is unknown. Prior to the application and adoption of iMGs in sport, their validity and feasibility require investigation to enable sporting organisations, clinicians, and the scientific community to be aware of the strengths and limitations of iMGs. Valid iMG data can inform player welfare, safety, and medical initiatives, directly related to long-term brain health.[4].

This four-phase study[4] aimed to determine; Phase 1) the validity of iMG kinematic magnitude measures against laboratory criterion standards, Phase 2) the on-field validity of iMGs via videoverification, Phase 3) iMG feasibility evaluated via player perceptions of fit, function and comfort, and Phase 4) practical feasibility of iMG systems from a practitioner perspective.

\section{METHODS}

\section{Study Design}

The four-phase study evaluated four currently available iMG systems, consistent with the published protocol.[4] Phase 1 validated the kinematic measures of iMGs against laboratory criterion standards.[2,3] Phase 2 evaluated the on-field validity of iMG-triggered events by identifying true-positives, false-positives and false-negatives via video-verification from 80 rugby league player matches ( $20 \pm 9$ player matches per iMG company). Phase 3 evaluated the fit, comfort and function,[5] of iMGs from a player's perspective, and Phase 4 evaluated the practical feasibility of the iMG system from a practitioner's perspective[6,7] using questionnaires.

\section{Instrumented Mouthguard Recruitment}

85 iMG companies were invited to provide 43 iMGs ( $n=3$ Phase $1, n=20$ Phase 2, $n=20$ Phase

86 3) and associated systems free of charge. The protocol[4] was shared, and companies were 87 informed that the findings would help determine the appropriateness of iMGs for the TaCKLE 88 (Tackle and Contact Kinematic, Load and Exposure) project.[8] Six iMG companies were initially 
Table 1. Hardware provided for the study, and product specification of iMGs and associated systems.

\begin{tabular}{|c|c|c|c|c|}
\hline & FRI & HitIQ & $\begin{array}{c}\text { ORB } \\
\text { Innovations }\end{array}$ & $\begin{array}{c}\text { Prevent } \\
\text { Biometrics }\end{array}$ \\
\hline Company Details & $\begin{array}{c}\text { Football Research } \\
\text { Inc (FRI)*, New } \\
\text { York, USA }\end{array}$ & $\begin{array}{l}\text { HitIQ, Melbourne, } \\
\text { Australia }\end{array}$ & $\begin{array}{l}\text { ORB innovations, } \\
\text { London, UK }\end{array}$ & $\begin{array}{l}\text { Prevent Biometrics, } \\
\text { Minnesota, USA }\end{array}$ \\
\hline Hardware Provided & $\begin{array}{c}43 \text { iMGs } \\
2 \text { Control cases } \\
3 \text { Laptops }\end{array}$ & $\begin{array}{c}54 \text { iMGs } \\
8 \text { Control cases } \\
8 \text { iPads }\end{array}$ & $\begin{array}{c}23 \text { iMG } \\
4 \text { Control cases } \\
1 \text { iPhone }\end{array}$ & $\begin{array}{c}43 \text { iMGs } \\
6 \text { Control cases } \\
7 \text { iPads }\end{array}$ \\
\hline Sensor Type & $\begin{array}{c}\text { Linear } \\
\text { Accelerometer; } \\
\text { Angular } \\
\text { Accelerometer }\end{array}$ & $\begin{array}{l}\text { Linear } \\
\text { Accelerometer; } \\
\text { Gyroscope }\end{array}$ & $\begin{array}{l}\text { Linear } \\
\text { Accelerometer; } \\
\text { Gyroscope }\end{array}$ & $\begin{array}{l}\text { Linear } \\
\text { Accelerometer; } \\
\text { Gyroscope }\end{array}$ \\
\hline Linear Sampling Rate & $5500 \mathrm{~Hz}$ & $3200 \mathrm{~Hz}$ & $1600 \mathrm{~Hz}^{\mathrm{a}}$ & $3200 \mathrm{~Hz}$ \\
\hline $\begin{array}{l}\text { Angular Sampling } \\
\text { Rate }\end{array}$ & $5500 \mathrm{~Hz}$ & $800 \mathrm{~Hz}$ & $1600 \mathrm{~Hz}^{\mathrm{a}}$ & $3200 \mathrm{~Hz}$ \\
\hline $\begin{array}{l}\text { Linear Measurement } \\
\text { Range }\end{array}$ & $\pm 400 \mathrm{~g}$ & $\pm 200 \mathrm{~g}$ & $\pm 200 \mathrm{~g}$ & $\pm 200 \mathrm{~g}$ \\
\hline $\begin{array}{l}\text { Angular } \\
\text { Measurement Range }\end{array}$ & $\pm 20 \mathrm{krad} / \mathrm{s}^{2}$ & $\pm 34.9 \mathrm{rad} / \mathrm{s}$ & $\pm 34.9 \mathrm{rad} / \mathrm{s}$ & $\pm 34.9 \mathrm{rad} / \mathrm{s}$ \\
\hline $\begin{array}{l}\text { Output Time Windows } \\
\text { (ms) }\end{array}$ & $\begin{array}{c}71 \mathrm{~ms} \\
\text { (21 ms pre-trigger; } \\
50 \mathrm{~ms} \text { post-trigger) }\end{array}$ & $\begin{array}{c}100 \mathrm{~ms} \\
\text { (20 ms pre-trigger; } \\
80 \mathrm{~ms} \text { post-trigger) }\end{array}$ & $\begin{array}{c}100 \mathrm{~ms} \\
\text { (51 ms pre-PLA } \\
\text { peak; } 49 \text { ms post- } \\
\text { PLA peak) }\end{array}$ & $\begin{array}{c}50 \mathrm{~ms} \\
\text { (10 ms pre-trigger; } \\
40 \mathrm{~ms} \text { post-trigger) }\end{array}$ \\
\hline $\begin{array}{l}\text { Output Coordinate } \\
\text { System and Origin }\end{array}$ & $\begin{array}{c}\text { SAE-J211; } \\
\text { Head CG } \\
11 \text { consecutive raw }\end{array}$ & $\begin{array}{c}\text { SAE-J211; } \\
\text { Head CG } \\
\text { Single raw sample }\end{array}$ & $\begin{array}{c}\text { Sensor } \\
\text { Sinqle raw sample }\end{array}$ & $\begin{array}{c}\text { SAE-J211; } \\
\text { Head CG } \\
\text { Single raw sample }\end{array}$ \\
\hline Trigger Mechanism ${ }^{b}$ & $\begin{array}{c}\text { samples exceed } 10 \\
g \text { on single axis of } \\
\text { accelerometer }\end{array}$ & $\begin{array}{l}\text { exceeds } 13 \mathrm{~g} \text { on } \\
\text { single axis of } \\
\text { accelerometer } \\
\text { Single filtered }\end{array}$ & $\begin{array}{l}\text { exceeds } 10 \mathrm{~g} \\
\text { (resultant value) at } \\
\text { accelerometer }\end{array}$ & $\begin{array}{l}\text { exceeds } 8 \mathrm{~g} \text { on } \\
\text { single axis of } \\
\text { accelerometer }\end{array}$ \\
\hline $\begin{array}{l}\text { Recording Threshold } \\
\text { Value }^{c}\end{array}$ & $\begin{array}{l}\text { All iMG-triggered } \\
\text { events used }\end{array}$ & $\begin{array}{c}\text { sample exceeds } 13 \\
g \text { (resultant value }) \\
\text { at head CG }\end{array}$ & $\begin{array}{l}\text { All iMG-triggered } \\
\text { events used }\end{array}$ & $\begin{array}{l}\text { All iMG-triggered } \\
\text { events used }\end{array}$ \\
\hline Filter Type & CFC 180 & Butterworth ${ }^{d}$ & None & $\begin{array}{l}\text { Butterworth, fourth } \\
\text { order zero-phase } \\
\text { (2x2 pole), low-pass }\end{array}$ \\
\hline $\begin{array}{l}\text { Filter Cutoff } \\
\text { Frequency }\end{array}$ & $300 \mathrm{~Hz}(-3 \mathrm{~dB})$ & $300 \mathrm{~Hz}^{\mathrm{d}}$ & $\mathrm{N} / \mathrm{A}$ & $200 \mathrm{~Hz}(-6 \mathrm{~dB})^{\mathrm{e}}$ \\
\hline $\begin{array}{l}\text { Data processing } \\
\text { pipeline }\end{array}$ & $\begin{array}{l}\text { Data manually sent } \\
\text { within 1-2 days }\end{array}$ & $\begin{array}{c}\text { Data } \\
\text { instantaneously } \\
\text { accessed from } \\
\text { HitlQ portal }\end{array}$ & $\begin{array}{l}\text { Data manually sent } \\
\text { within 1-2 days }\end{array}$ & $\begin{array}{c}\text { Data } \\
\text { instantaneously } \\
\text { accessed from } \\
\text { Prevent portal }\end{array}$ \\
\hline
\end{tabular}
recorded at either $30 \mathrm{~Hz}$ ( $\mathrm{n}=2$ player matches) or $100 \mathrm{~Hz}(\mathrm{n}=7$ player matches) in Phase 2 due to software issues. was determined by the iMG company. 'Recording threshold refers to any threshold applied after triggering process. 
medRxiv preprint doi: https://doi.org/10.1101/2022.01.28.22270039; this version posted January 30, 2022. The copyright holder for this preprint (which was not certified by peer review) is the author/funder, who has granted medRxiv a license to display the preprint in perpetuity.

All rights reserved. No reuse allowed without permission.

\section{Phase 1 - Laboratory Validation of Kinematic Measures}

In-laboratory testing to evaluate the validity of $\mathrm{iMG}$ kinematic magnitudes was conducted at the Virginia Tech Helmet Lab (USA),[2] using a bareheaded dummy headform (Figure 1a) $[9,10]$ impacted at various locations, impact magnitudes (target linear head accelerations 25, 50, 75, and $100 \mathrm{~g}$ ) and durations (rigid; nylon, $25 \mathrm{~mm}$ thickness, and padded; vinyl-nitrile foam, $40 \mathrm{~mm}$ thickness) using a pendulum impactor (127 mm diameter) (Figure 1b) as previously described.[4] Two tests were conducted at each configuration and three iMGs were tested for each iMG company (Figure 1c). Reference kinematics were measured at the headform centre of gravity with an instrumentation package consisting of three linear accelerometers (Endevco 7264b-2000; Meggitt Orange County, Irvine, CA) and a tri-axial angular rate sensor (DTS ARS3 Pro 18k; Diversified Technical Systems, Seal Beach, CA), recording at $20 \mathrm{kHz}$, and filtered using a CFC 1000 and CFC 155. Custom-fit iMGs were mounted inside the headform as previously described.[4] HitlQ repeated testing, due to an issue with one test configuration producing high errors during the first round. HitlQ believed this was due to the use of their non-research data portal and/or experimental error. HitlQ implemented a firmware update and provided access to a research portal for the second round of testing. Football Research Inc [FRI] conducted three additional tests at the lowest speed test configuration. During the first round of testing, this configuration did not record as it was below the specific set iMG-trigger threshold. ORB updated the impact data analysis to account for an issue involving the impact detection algorithm and the iMGs two onboard accelerometers. ORB noted their algorithm sometimes saved data from the iMGs low- instead of high range accelerometer ( \pm 16 vs. $\pm 200 \mathrm{~g}$ ). Prevent had previously been tested in this laboratory using the same methodology.[2] HitlQ undertook pilot testing, independent of the research team in this laboratory prior to the study. Peak resultant linear acceleration (PLA), peak resultant angular velocity (PAV), and peak resultant angular acceleration (PAA) were recorded.[4] 
a)

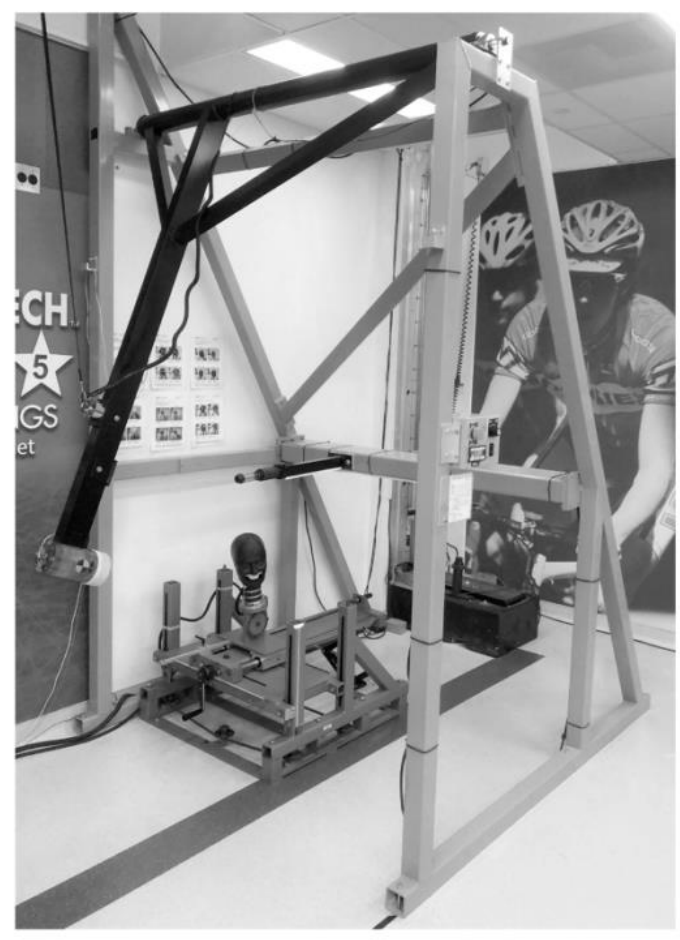

b)

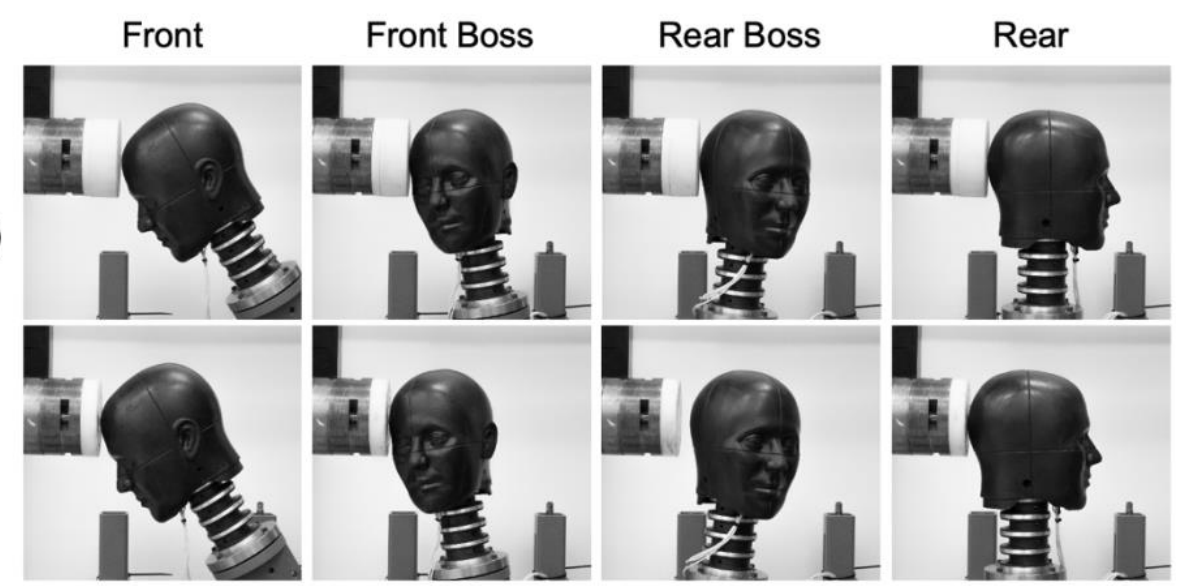

c)

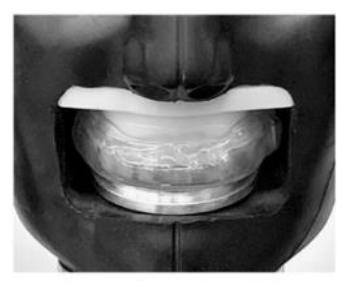

HitlQ

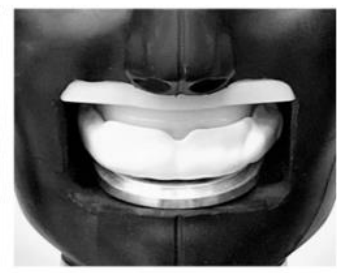

ORB Innovations Prevent Biometrics
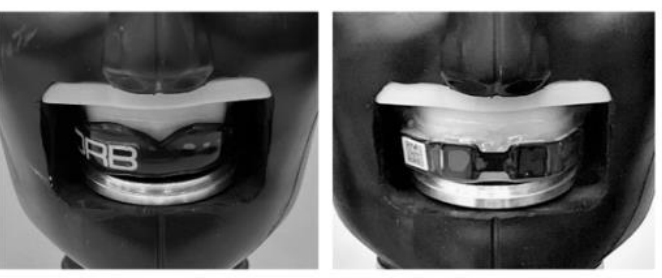

Figure 1. (a) Experimental set-up of pendulum impactor to simulate bareheaded impacts to the dummy headform. (b) Padded (vinyl-nitrile) and rigid (nylon) impactor to the bareheaded dummy headform at the front, front boss, rear boss, and rear locations of the headform. (c) The custom-fit iMG mounted inside the headform with detachable 3D-printed detention. 
medRxiv preprint doi: https://doi.org/10.1101/2022.01.28.22270039; this version posted January 30, 2022. The copyright holder for this preprint (which was not certified by peer review) is the author/funder, who has granted medRxiv a license to display the preprint in perpetuity.

All rights reserved. No reuse allowed without permission.

\section{Phase 2 - On-Field Validity}

Fifty-one male rugby league players from five Super League academies underwent 3D dental scans, performed by an experienced dentist, and reviewed by a third-party dentist with experience in iMG manufacture. Each company manufactured the custom-fit iMGs, for two teams, based on dental details received via a standard language tessellation file. HitIQ provided 11 additional iMGs at the request of the research team to increase match observations. Due to injuries, suspensions, and non-compliance of iMG wearing eighty player matches were included ( $n$ = players wearing iMG/players received dental scans [player matches]; FRI $n=10 / 20$ [17], HitIQ $n=18 / 31$ [28], ORB $n=7 / 20$ [9], and Prevent $n=12 / 20$ [27]). For ORB, manufacturing delays reduced data collection, and battery issues resulted in 6/9 player matches having partial data collected (mean duration $=30: 22 \pm$ 09:51 mins). One player removed their Prevent iMG five minutes into a match, so data were only partially captured for this match.

All data collection and management were undertaken by the research team as per manufacturer instructions. Events recorded by iMGs were time-synchronized with high-quality video footage of match-play recorded by the home team to verify whether each iMG-triggered event (post application of companies' recording threshold and/or HAE detection algorithm, if applicable) was associated with a HAE for the instrumented player. Companies determined the iMG recording and trigger thresholds (Table 1), as previously described.[4] iMG data were trimmed to synchronize with kick-off and 10 minutes post-match, resulting in data being recorded during the half-time period.

To determine true-positives or false-positives, a guided analysis was undertaken. iMG-triggered events were classified by a trained video analyst as true-positives, false-positives or assumed false-positives (Table 2). To determine false-negatives, an unguided analysis was undertaken. One professional rugby video analyst tracked each player wearing an iMG during matches and labelled their one-on-one shoulder tackles when a tackler.[11] The timestamp of each labelled one-on-one shoulder tackle event was cross-referenced with the iMG-triggered dataset. Truepositives or false-negatives were based on whether the one-on-one shoulder tackle event timestamp matched an iMG-triggered timestamp (Table 2). Only periods of play where iMGs were collecting data were used to avoid false-negatives being labelled when iMGs were not worn or active. The collection, analysis and reporting is consistent with the published protocol.[4] Additional analysis and reporting of variables included quantification of player activities during 
medRxiv preprint doi: https://doi.org/10.1101/2022.01.28.22270039; this version posted January 30, 2022. The copyright holder for this preprint (which was not certified by peer review) is the author/funder, who has granted medRxiv a license to display the preprint in perpetuity.

All rights reserved. No reuse allowed without permission.

165 identified false-positives, a breakdown of false-negatives, and iMG kinematic magnitudes during 166 match-play.

167 
Table 2. True-positive, false-positive, assumed false-positive, false-negative definitions during for the guided and unguided analysis (Phase 2).

\begin{tabular}{|c|c|c|c|c|c|c|}
\hline & True-Positive & False-Positive & $\begin{array}{l}\text { Assumed False-Positive } \\
\text { (Off-Camera) } \\
\text { Guided analysis }\end{array}$ & $\begin{array}{l}\text { Assumed False- } \\
\text { Positive (Inactive) }\end{array}$ & \multicolumn{2}{|c|}{ Unguided analysis } \\
\hline $\begin{array}{l}\text { iMG-triggered } \\
\text { event }\end{array}$ & Impact reported & Impact reported & Impact reported & Impact reported & Impact reported & Impact not reported \\
\hline Video Footage & $\begin{array}{c}\text { Video footage } \\
\text { shows a visible } \\
\text { HAE from a } \\
\text { contact event at } \\
\text { an iMG-triggered } \\
\text { event timestamp. }\end{array}$ & $\begin{array}{l}\text { Video footage } \\
\text { shows that } \\
\text { player does not } \\
\text { have a visible } \\
\text { HAE from a } \\
\text { contact event at } \\
\text { timestamp of } \\
\text { iMG-triggered } \\
\text { event }\end{array}$ & $\begin{array}{l}\text { iMG-triggered event occurs } \\
\text { during active match-play whilst } \\
\text { the instrumented player is on the } \\
\text { field. The instrumented player is } \\
\text { not visible on the video footage. } \\
\text { Given the video footage is } \\
\text { following play (i.e., the ball, } \\
\text { tackles and carries), it is } \\
\text { assumed this is a false-positive. }\end{array}$ & $\begin{array}{l}\text { iMG-triggered event } \\
\text { occurs during half- } \\
\text { time or during the 10- } \\
\text { minute period } \\
\text { following full-time. } \\
\text { Video footage is not } \\
\text { available to confirm if } \\
\text { a HAE occurred (e.g., } \\
\text { during warm up } \\
\text { tackles) }\end{array}$ & $\begin{array}{l}\text { Instrumented } \\
\text { player is } \\
\text { involved in a } \\
\text { one-on-one front } \\
\text { on shoulder } \\
\text { tackle, as the } \\
\text { tackler. }\end{array}$ & $\begin{array}{l}\text { Instrumented player } \\
\text { is involved in a one- } \\
\text { on-one front on } \\
\text { shoulder tackle, as } \\
\text { the tackler. }\end{array}$ \\
\hline
\end{tabular}


medRxiv preprint doi: https://doi.org/10.1101/2022.01.28.22270039; this version posted January 30, 2022. The copyright holder for this preprint (which was not certified by peer review) is the author/funder, who has granted medRxiv a license to display the preprint in perpetuity.

All rights reserved. No reuse allowed without permission.

171 Phase 3 - Player feasibility (perception of fit, comfort and function)

172 Eighteen male rugby league players with no prior experience of iMGs, from four Super League

173 clubs, received one iMG from each company $(n=4)$, following dental scans as per Phase 2. Using

174 a randomised cross-over design between clubs, each iMG was worn during two training sessions

175 (>45-minutes). Within one hour following the second training session, players rated the fit, comfort

176 and function of $\mathrm{iMGs}^{5}$ ] using an online questionnaire (Qualtrics ${ }^{\mathrm{XM}}$, Washington, USA). This

177 resulted in the completion of four questionnaires for each iMG. The research team supervised

178 players to ensure the questionnaires were completed independent of other players. Fit, comfort

179 and function were evaluated using eight, six and four questions, answered on binary, 10- and 3-

180 point Likert scales.[5] Results were reported consistent with the protocol.[4]

181

182

183

184

185

186

187

188

\section{Phase 4 - Practitioner feasibility (perception of usability)}

Four physiotherapy / sports science practitioners with no prior experience of the iMG systems, from four different Super League clubs evaluated three iMG systems (HitIQ, Prevent, FRI) in a randomised cross-over design. ORB did not participate in Phase 4, at their request, due to the software requiring their interpretation and involvement. Usability was evaluated for 1) preparing iMG systems (e.g., setup, charging and deployment of the iMGs to participants) and 2) managing iMG data (e.g., extracting data to software interface, accessing information and feedback mechanisms within system). iMG companies provided an on-line 'on-boarding' session (observed by the research team) to familiarise practitioners with the operating procedures one day before initial use. Practitioners had access to operating procedure documentation, and support from research team/iMG companies if required. Practitioners completed the preparation and management of iMG systems on two training days. Within one hour of downloading data from second training session, practitioners completed two online System Usability Scale (SUS) $[6,7]$.

\section{Data Analysis}

201 Validity was assessed by calculating the concordance correlation coefficient (CCC) (Eq. 1), to 202 quantify the agreement between iMGs and reference measurements.[2] 


$$
\text { CCC }=\frac{2 \rho}{v+\frac{1}{v}+u^{2}} \text { where } v=\frac{S_{x}}{S_{y}} \text { and } u=\frac{\hat{x}-\hat{y}}{\sqrt{S_{x} S_{y}}}
$$

205

206

207

208

209

210

211

212

213

214

215

216

217

218

219

220

221

222

223

224

225

226

227

228

229

230

231

232

233

234

235

236

In Equation [1], $\rho$ represents the Pearson correlation coefficient, $x$ and y represent the reference and $\mathrm{iMG}$ measurements, respectively. $\hat{X}$ and $\hat{y}$ represent the measurement means, and $S_{x}$ and $S_{y}$ represent the measurement standard deviations (SD). iMG output the peak resultant values for linear (e.g., PLA) and rotational (e.g., PAA) kinematic measures. After the sensor and reference measurements were recorded, both were normalized relative to the maximum reference measurement. CCC values were computed for the linear and rotational kinematic measure(s), and the combination of linear and rotational measures. The combined CCC value that accounts for peak linear and rotational acceleration represented the overall iMG in-laboratory validity. However, the ORB iMG system was unable to output PAA, and thus PAV was utilized in their combined CCC value.

\section{Phase 2}

Positive predictive values (PPV) (Eq. 2) were calculated for true-positives and false-positives, as well as combinations of assumed false-positives (i.e., false-positives summed).[2]

$$
\text { Positive Predictive Value }=\frac{\text { True Positives }}{\text { True Positives }+ \text { False Positives }}
$$

A sensitivity score was calculated (Eq 3) from the true-positive and false-negative counts for each iMG.

\section{Phase 3}

Mean (range) percentage of positive responses (i.e., 'no') for individual questionnaire items, evaluating fit and function were calculated. Median and interquartile ranges were calculated from the 10-point Likert questionnaire items evaluating comfort.

\section{Phase 4}

The mean \pm SD of the two SUS scores (i.e., preparation and management) were calculated.

\section{RESULTS}


237 Table 3 presents in-laboratory (Phase 1) and on-field (Phase 2) validity, player evaluations of fit, 238 comfort and function (Phase 3) and practitioner SUS (Phase 4). The linear and angular kinematic 239 values for each iMG are shown in Figure 2 (Phase 1) and Figure 3 (Phase 2). Supplementary 240 Table 1 shows off-camera assumed false-positives and associated PPV, and a breakdown of 241 false-positives and false-negatives. Supplementary Table 2 shows true-positives, false-positives 242 and associated PPV for each player from Phase 2. Supplementary Table 3 shows the fit, comfort 243 and function for each questionnaire item from Phase 3. Supplementary Figure 2 shows the linear 244 and angular kinematic values, associated PPVs, true-positives, false-positives, and combinations 245 of false-positives and assumed false-positives for each iMG from Phase 2. 
Table 3. Laboratory (Phase 1) and on-field (Phase 2) validity and player (Phase 3) and practitioner (Phase 4) feasibility results

\begin{tabular}{|c|c|c|c|c|}
\hline & FRI & HitIQ & ORB & Prevent \\
\hline \multicolumn{5}{|l|}{ Phase 1} \\
\hline Linear CCC (\%) & 97.5 & 92.1 & 32.1 & 97.2 \\
\hline Rotational CCC (\%) & 98.9 & 97.9 & 43.1 & 98.0 \\
\hline Total CCC (\%) & 98.3 & 95.3 & 42.5 & 97.9 \\
\hline \multicolumn{5}{|l|}{ Phase 2 (False-Positive; Guided Analysis) } \\
\hline Player Matches $(n)$ & 17 & 28 & 9 & 27 \\
\hline $\begin{array}{l}\text { Total Impacts }(\mathrm{n}) \\
(\text { mean } \pm \text { SD per player, per match) }\end{array}$ & $\begin{array}{c}201 \\
(11.8 \pm 10.5)\end{array}$ & $\begin{array}{c}405 \\
(14.5 \pm 7.4)\end{array}$ & $\begin{array}{c}179 \\
(19.9 \pm 22.8)\end{array}$ & $\begin{array}{c}745 \\
(27.6 \pm 15.6)\end{array}$ \\
\hline $\begin{array}{l}\text { True-Positives }(\mathrm{n}) \\
\text { (mean } \pm \text { SD per player, per match) }\end{array}$ & $\begin{array}{c}162 \\
(9.5 \pm 5.1)\end{array}$ & $\begin{array}{c}245 \\
(8.8 \pm 5.2)\end{array}$ & $\begin{array}{c}66 \\
(7.3 \pm 11.7)\end{array}$ & $\begin{array}{c}666 \\
(24.7 \pm 14.6)\end{array}$ \\
\hline $\begin{array}{l}\text { False-Positives }(\mathrm{n}) \\
\text { (mean } \pm \text { SD per player, per match) } \\
\text { True-Positives and False-Positives PPV }\end{array}$ & $\begin{array}{c}4 \\
(0.2 \pm 0.4) \\
0.98\end{array}$ & $\begin{array}{c}28 \\
(1.0 \pm 1.2) \\
0.90\end{array}$ & $\begin{array}{c}59 \\
(6.6 \pm 7.7) \\
0.53\end{array}$ & $\begin{array}{c}45 \\
(1.7 \pm 2.3) \\
0.94\end{array}$ \\
\hline $\begin{array}{l}\text { Inactive Assumed False-Positives ( } \mathrm{n}) \\
\text { (mean } \pm \text { SD per player, per match) }\end{array}$ & $\begin{array}{c}30 \\
(1.8 \pm 7.0)\end{array}$ & $\begin{array}{c}21 \\
(0.8 \pm 1.2)\end{array}$ & $\begin{array}{c}7 \\
(0.8 \pm 2.3)\end{array}$ & $\begin{array}{c}0 \\
(0.0 \pm 0.0)\end{array}$ \\
\hline $\begin{array}{l}\text { True-Positives, False-Positives and } \\
\text { Inactive Assumed False-Positives PPV }\end{array}$ & 0.83 & 0.83 & 0.50 & 0.94 \\
\hline $\begin{array}{l}\text { All Assumed False-Positives ( } \mathrm{n}) \\
\text { (mean } \pm \text { SD per player, per match) }\end{array}$ & $\begin{array}{c}35 \\
(2.1 \pm 7.2)\end{array}$ & $\begin{array}{c}132 \\
(4.7 \pm 4.9)\end{array}$ & $\begin{array}{c}54 \\
(6.0 \pm 5.8)\end{array}$ & $\begin{array}{c}34 \\
(1.3 \pm 2.8)\end{array}$ \\
\hline $\begin{array}{l}\text { True-Positives, False-Positives and all } \\
\text { Assumed False-Positives PPV }\end{array}$ & 0.81 & 0.60 & 0.37 & 0.89 \\
\hline \multicolumn{5}{|c|}{ Phase 2 (False-Negative; Unguided Analysis) } \\
\hline True-Positive (n) & 47 & 49 & 20 & 82 \\
\hline False-Negative (n) & 46 & 73 & 8 & 27 \\
\hline Sensitivity (\%) & 0.51 & 0.40 & 0.71 & 0.75 \\
\hline \multicolumn{5}{|l|}{ Phase 3} \\
\hline Fit (mean \% [range]) & $77(16,100)$ & $88(63,100)$ & $65(22,94)$ & $85(67,100)$ \\
\hline Comfort (median [IQR]) & $6(5,7)$ & $8(6,8)$ & $5(3,7)$ & $8(7,8)$ \\
\hline Function (mean \% [range]) & $55(16,100)$ & $61(21,95)$ & $43(11,83)$ & $67(44,94)$ \\
\hline \multicolumn{5}{|l|}{ Phase 4} \\
\hline Preparation (SUS score out of 100) & $51.3 \pm 21.7$ & $71.3 \pm 20.7$ & - & $83.8 \pm 21.3$ \\
\hline Management (SUS score out of 100 ) & $50.6 \pm 28.5$ & $78.8 \pm 11.1$ & - & $80.0 \pm 20.7$ \\
\hline
\end{tabular}

250

251

252

253

254

255

Note: All assumed false-positives are for summed off-camera and inactive assumed falsepositives; off-camera assumed false-positives are shown in Supplementary Table 1; Preparation and Management are reported as mean and standard deviation; CCC $=$ Concordance Correlation Coefficient; PPV = Positive Predictive Values; SUS = system usability scale; IQR = inter-quartile range. 
a)

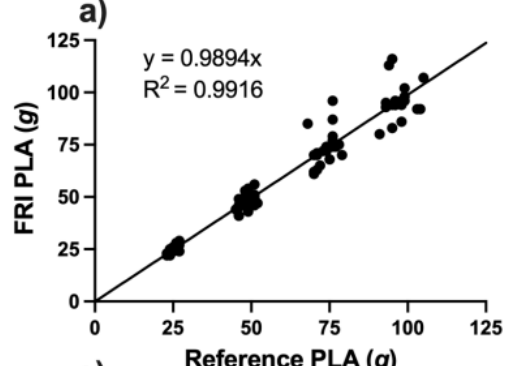

e) Reference PLA ( $g$ )

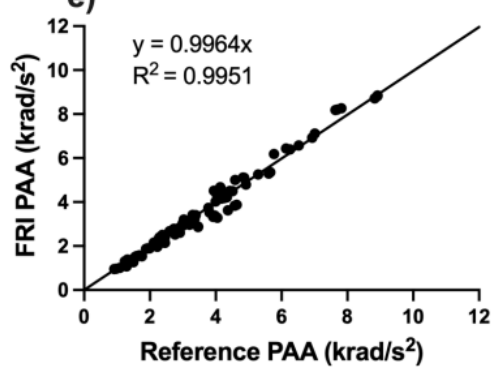

b)

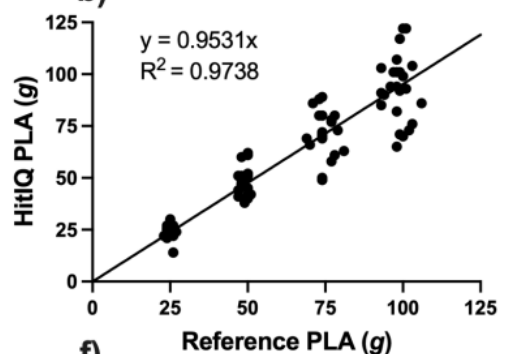

f)

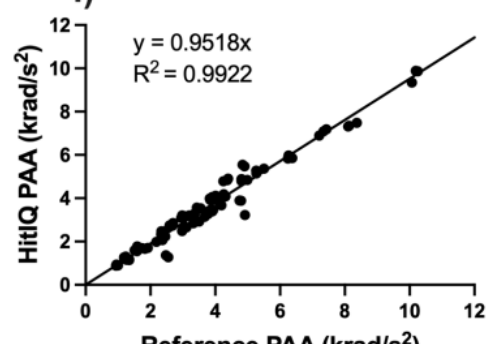

Reference PAA (krad/s $\mathbf{s}^{2}$ ) c)

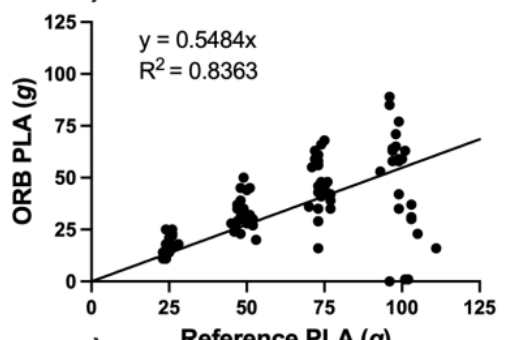

g)

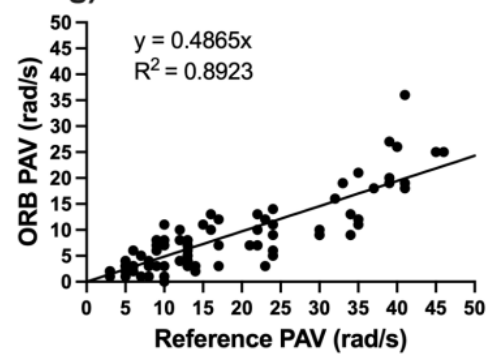

d)

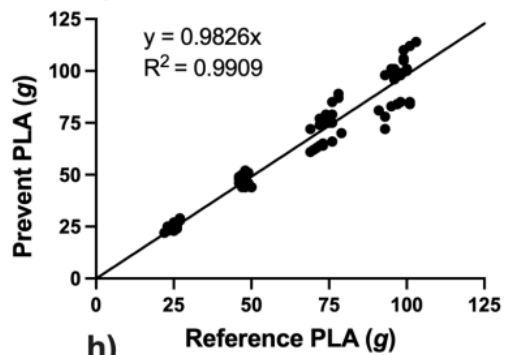

h)

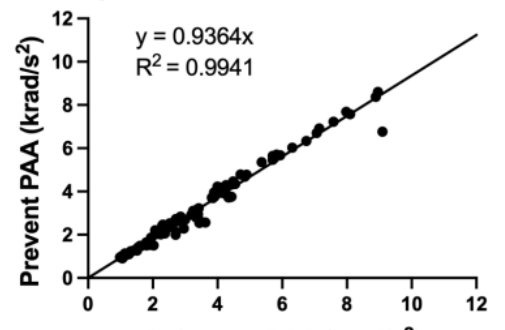

Reference PAA (krad/s ${ }^{2}$ )

Figure 2. Linear (a) FRI, b) HitlQ, c) ORB, d) Prevent) and angular (e) FRI, f) HitIQ, g) ORB, h) Prevent) kinematic values for each iMG and reference measurements during laboratory bareheaded dummy headform impacts. 

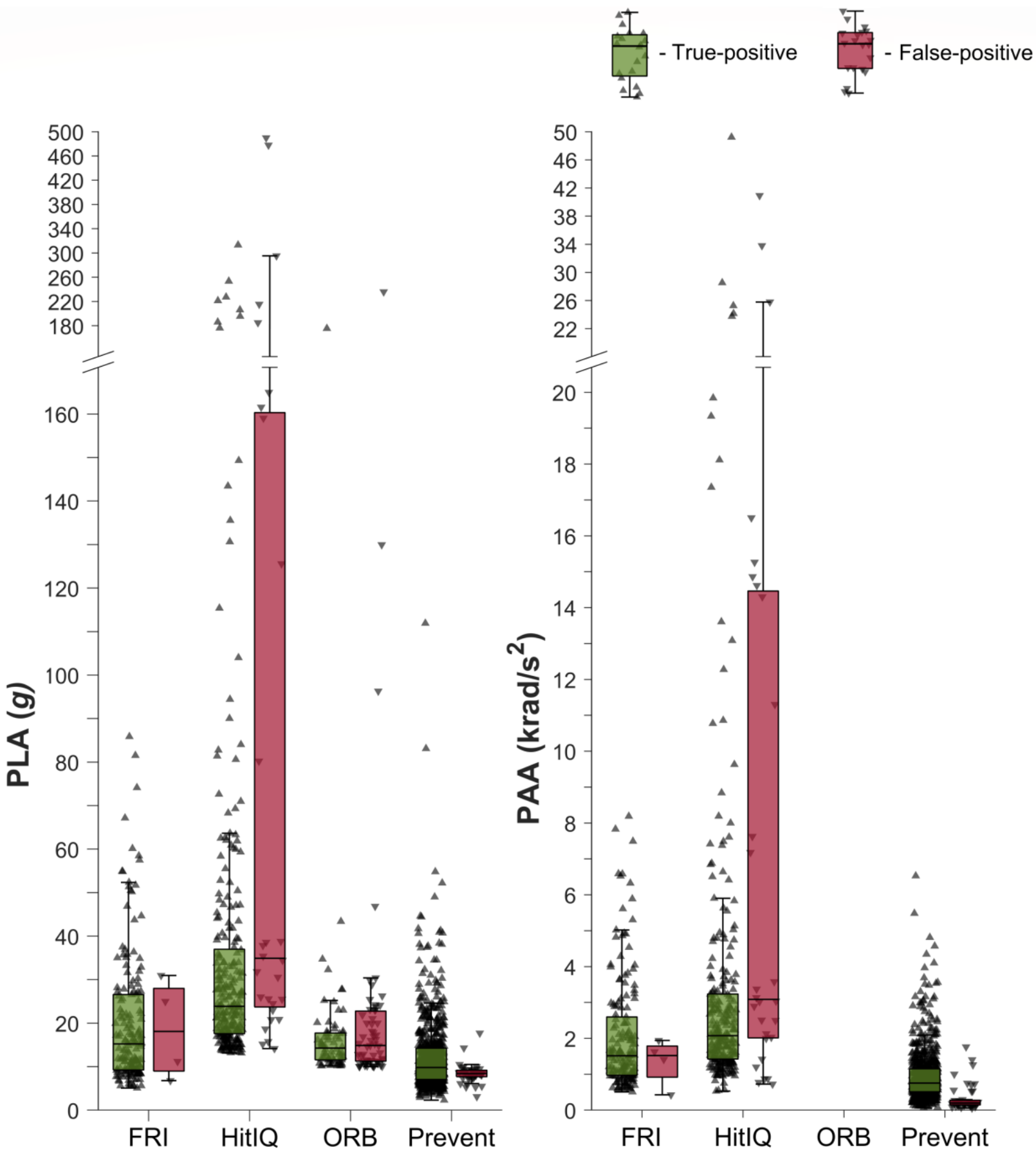

Figure 3. Linear and angular on-field kinematic values from true-positives and falsepositives for each iMG from Phase 2. Note ORB did not provide PAA, thus not presented.

\section{DISCUSSION}

This study was the first to determine the validity and feasibility of current iMGs and associated systems, which is vital to consider the error associated with HAE data and maximise the adoption of iMG systems in sport. In Phase 1, FRI, HitlQ, ORB and Prevent had total CCC of 98.3\%, 95.3\%, 
medRxiv preprint doi: https://doi.org/10.1101/2022.01.28.22270039; this version posted January 30, 2022. The copyright holder for this preprint (which was not certified by peer review) is the author/funder, who has granted medRxiv a license to display the preprint in perpetuity.

All rights reserved. No reuse allowed without permission.

42.5\% and 97.9\% when compared with dummy headform reference measurements.[2] Falsepositive (PPV) and false-negative performance (sensitivity) should be considered simultaneously in Phase 2. Overall, Prevent had the highest performance with a PPV of 0.94 and sensitivity of 0.75. For $\mathrm{FRI}$ and $\mathrm{HitlQ}$, false-positive performance was higher (PPV $=0.98$ and 0.90 , respectively) than false-negative performance (sensitivity $=0.51$ and 0.40 , respectively). ORB had a higher false-negative (sensitivity $=0.75$ ), but lower false-positive (PPV 0.53) performance. To understand likely iMG adoption, the feasibility of current iMG systems were determined. In Phase 3, players reported HitlQ and Prevent to have similar, and FRI and ORB lower ratings for fit, comfort and function. Practitioners reported the SUS to be highest for Prevent $(>80)$, followed by HitlQ (>70) and FRI (>50). This study demonstrates differences between current iMG systems exist. These findings can be used by sporting organisations to determine the appropriateness of iMG systems, and provides reference data to improve the validity and feasibility of iMG systems, optimising their adoption in sport, supporting player welfare initiatives directly related to long-term brain health.

For Phase 1, FRI, HitlQ, and Prevent had total CCC values $>95 \%$, higher than other wearable head sensors previously evaluated.[2] All iMGs achieved higher CCC for PAA than PLA (Table 3). Varying in-laboratory iMG performance has previously been observed (e.g., mean error of $32.4 \%$ for PLA[3]) which was attributed to a lack of filtering of iMG kinematic data.[12] This highlights the importance of ongoing hardware/firmware/data-processing development to improve the validity of kinematic data, but also poses a challenge for researchers and practitioners if proprietary algorithms are frequently updated exclusive of independent validation.[13] As such, this study should be repeated, given the rapid development of existing, and emergence of new iMG systems.

Phase 2 evaluated the on-field validity of iMGs (PPV; true-positives and false-positives and sensitivity; true-positives and false-negatives). Prevent had the highest concurrent false-positive and false-negative performance. Both FRI and HitlQ demonstrated high false-positive, but lower false-negative performance, and ORB demonstrated high false-negative, but lower false-positive performance. The different performance by iMGs may be due to the trigger and recording thresholds set by iMG companies, and/or HAE detection algorithms. Prevent had the lowest trigger threshold $(8 \mathrm{~g})$, vs. FRI, ORB (both $10 \mathrm{~g}$ ) and HitlQ (13 g), which likely improved falsenegative performance when compared to the other iMGs. Lower trigger thresholds could result in more false-positives (due to lower-magnitude iMG-triggered non-HAE being captured) and fewer 
medRxiv preprint doi: https://doi.org/10.1101/2022.01.28.22270039; this version posted January 30, 2022. The copyright holder for this preprint (which was not certified by peer review) is the author/funder, who has granted medRxiv a license to display the preprint in perpetuity.

All rights reserved. No reuse allowed without permission.

false-negatives. Most false-positives observed for Prevent (78\%) occurred whilst players were running (Supplementary Table 1). These may represent true head accelerations from inertial loading during non-contact events,[14,15] necessitating HAE detection algorithms to differentiate contact from non-contact events.[1] This study defined true-positives as HAE during contact events, however HAE from non-contact events (e.g., running and jumping) may also be desirable in future studies. Further analysis of false-negatives for FRI revealed that the iMG algorithm incorrectly binned $17.4 \%$ of false-negatives. The FRI algorithm was trained on American Football data,[16] therefore optimising the algorithm using non-helmeted sports would likely improve falsenegative performance. HitlQ false-negative performance was likely due to the $13 \mathrm{~g}$ recording threshold, which was different to the trigger threshold (Table 1). Further analysis of HitIQ data revealed that $42.5 \%$ of false-negatives were collected as iMG-triggered events, but subsequently binned as they fell below the $13 \mathrm{~g}$ recording threshold, and $1.4 \%$ of false-negatives were greater than the recording threshold but were misclassified by the iMG algorithm (Supplementary Table 1). Decreasing the $13 \mathrm{~g}$ recording threshold (or removing it entirely) may improve HitlQ's falsenegative performance, however the effect this would have on false-positive performance is unknown. Increasing the ability to remove false-positives would improve the overall performance of ORB.

When off-camera and inactive assumed false-positives are considered, false-positive performance reduced for all iMGs (FRI, PPV $=0.98$ to 0.81 ; HitlQ, PPV $=0.90$ to 0.60 ; ORB, PPV $=0.53$ to 0.37 ; Prevent, PPV $=0.94$ to 0.89 ; Supplementary Figure 1 ). No inactive assumed falsepositives were observed for Prevent (Supplementary Table 1) which may be due to proximity sensors embedded within Prevent iMGs, allowing for iMG-triggered events which occurred whilst the iMG was not on the players' teeth to be removed by the iMG. HitIQ and ORB accumulated more off-camera assumed false-positives, and HitIQ and FRI accumulated more assumed falsepositives during inactive periods $(93.5 \%$ of these for FRI came from a single iMG, which may have been faulty; Supplementary Table 1 and 2). Therefore video-verification or alignment to another data-source (e.g., time motion analysis of match events [17]) may be required prior to use in research and/or practice.

Validating the kinematics of on-field HAE is beyond the scope of this study, due to a lack of an accurate reference sensor. Whilst FRI, HitlQ and Prevent all had similar kinematics CCC in Phase 1 (Table 3 and Figure 2), the kinematics between iMGs from Phase 2 varied and some exceeded the $100 \mathrm{~g}$ magnitude used in Phase 1. Whilst median kinematic data are influenced by different 
medRxiv preprint doi: https://doi.org/10.1101/2022.01.28.22270039; this version posted January 30, 2022. The copyright holder for this preprint (which was not certified by peer review) is the author/funder, who has granted medRxiv a license to display the preprint in perpetuity.

All rights reserved. No reuse allowed without permission.

thresholds, the number and range of high magnitude true-positives differ (Figure 2). The number of true-positives with a PLA above 100 and $200 \mathrm{~g}$, were zero and zero for FRI, 14 and five for HitlQ, one and zero for Prevent and one and zero for ORB. Similarly, for true-positives which had a PAA above 10 and $20 \mathrm{krad} / \mathrm{s}^{2}$, HitlQ reported 14 and five, whilst $\mathrm{FRI}$, ORB and Prevent all reported none. Measuring the kinematics of on-field HAE is associated with numerous challenges including mandible action (e.g., biting), adherence to teeth and vocalisation, which may affect the magnitude of peak kinematics by introducing noise into iMG signals. It is outside of the scope of this study to evaluate the on-field HAE kinematics, however future studies should investigate the kinematic traces to evaluate signal noise of on-field events.

To optimise iMG adoption, Phase 3 and 4 evaluated the feasibility from a player and practitioner perspective. Most players perceived no issues with the iMGs for fit (mean response of 'no' = 62 to $88 \%$ ). Individual questionnaire items revealed players perceived FRI and ORB 'too bulky' (84\% and $79 \%$ of players), with fewer expressing this perception for HitlQ and Prevent (37\% and 33\% of players; Supplementary Table 3). HitlQ and Prevent (both 8/10) had higher median scores for comfort, than FRI and ORB (6/10, 5/10; Table 2). In a previous study,[5] a mouthguard intentionally containing common design faults had a median comfort rating of 6/10, which can be used as a comparison. For FRI, HitIQ and Prevent, most players (55 to 67\%) perceived no issues with the function of iMGs. This was lower for ORB (43\%; Supplementary Table 3), where $50 \%$ of players perceived it interfered with speech 'a lot' in comparison to FRI (26\%), HitIQ (11\%), and Prevent (17\%). As such, the design of iMGs (including the housing and positioning of component parts) is a key consideration for companies when considering the adoption of iMGs within sport.

Phase 4 evaluated the usability for FRI, HitlQ and Prevent system preparation and data management. The industry standard of average SUS for internet-based web pages and applications is 68, which both HitlQ (>70) and Prevent (>80) surpassed. FRI was lower (>50), which could influence adoption by practitioners. Both the system preparation and data management scores were similar within iMGs, which may suggest companies have prioritised these areas within their product development or indicate practitioners do not differentiate between these two aspects. The findings of Phase 3 and 4 provide comparative data for iMG evaluation and development, and potential system adoption.

iMGs have the potential to enhance clinical care via the live (where possible) and retrospective monitoring of HAEs. Both the frequency and magnitude of HAEs that athletes experience within 
medRxiv preprint doi: https://doi.org/10.1101/2022.01.28.22270039; this version posted January 30, 2022. The copyright holder for this preprint (which was not certified by peer review) is the author/funder, who has granted medRxiv a license to display the preprint in perpetuity.

All rights reserved. No reuse allowed without permission.

a match, training week, over a season and career can be used to inform player welfare initiatives. Practically, iMGs have the potential to contribute to concussion detection systems, contact load monitoring and return to play practices, which are all priorities in sport.

\section{Limitations}

This study is not without its limitations. Whilst peak resultant kinematic values are important, so are other signal characteristics such as pulse-time and frequency content, not assessed in Phase 1. iMG companies determined their own recording or trigger thresholds, influencing Phase 2 performance. It is unclear if false-negatives associated with no iMG-triggered event were due to one-on-one shoulder tackles not exceeding trigger thresholds or whether iMGs did not capture HAE events for another reason. iMGs should record data from all contact events, regardless of magnitude to gain a robust understanding of player HAE. Only one camera view was available for Phase 2, thus some iMG-triggered events could not be verified. Given the camera followed the ball, and every tackle, these iMG-triggered events were assumed false-positives and not the result of contact events. Future studies should use multiple camera angles to capture all iMGtriggered events during match-play. Not all iMG companies used automatic data processing pipelines for Phase 1 and 2 which may be advantageous for larger-scale project given the amount of data produced (Table 1), and was not assessed in Phase 4. Finally, to allow iMG companies to optimise algorithms and re-test performance, and to consider new iMGs this study should be repeated. To satisfy this point, it is proposed that this protocol is repeated with data collection starting in April 2022.

In conclusion, for the first time this study evaluated the validity and feasibility of current iMG systems, which have potential to provide data on HAE, and inform player welfare initiatives directly related to long-term brain health. This study showed that when compared with reference measurements from a dummy headform, FRI, HitlQ, Prevent had lower, and ORB had higher measurement error. When video-verification was used to determine on-field validity, Prevent had the highest false-negative performance, and second-highest false-positive performance. FRI and HitlQ had higher false-positive performance than false-negative performance, and ORB had higher false-negative performance than false-positive performance. To support the adoption of the iMG systems by players and practitioners, feasibility ratings were provided. HitlQ and Prevent achieved similar high ratings for fit, comfort and function, and practitioners reported the feasibility of iMG systems to be highest for Prevent, followed by HitIQ, then FRI. For the first time, this study provides data on the strengths and limitations of iMG systems. This can be used by sporting 
medRxiv preprint doi: https://doi.org/10.1101/2022.01.28.22270039; this version posted January 30, 2022. The copyright holder for this preprint (which was not certified by peer review) is the author/funder, who has granted medRxiv a license to display the preprint in perpetuity.

All rights reserved. No reuse allowed without permission.

404

405

406

407

408

409

410

411

412

413

414

415

416

417

418

419

420

421

422

423

424

425

426

427

428

429

430

431

432

433

434

435

436

437

organisations and provides reference data for iMG systems to optimize hardware and software, to improve both the validity of iMG data and feasibility of iMG systems from a player and practitioner perspective, optimizing the adoption of iMGs in sport.

\section{REFERENCES}

1 Tierney G. Concussion biomechanics, head acceleration exposure and brain injury criteria in sport: a review. Sports Biomech 2021;0:1-29. doi:10.1080/14763141.2021.2016929

2 Kieffer EE, Begonia MT, Tyson AM, et al. A Two-Phased Approach to Quantifying Head Impact Sensor Accuracy: In-Laboratory and On-Field Assessments. Ann Biomed Eng 2020;48:2613-25. doi:10.1007/s10439-020-02647-1

3 Liu Y, Domel AG, Yousefsani SA, et al. Validation and Comparison of Instrumented Mouthguards for Measuring Head Kinematics and Assessing Brain Deformation in Football Impacts. Ann Biomed Eng 2020;48:2580-98. doi:10.1007/s10439-020-02629-3

4 Tierney G, Weaving D, Tooby J, et al. Quantifying head acceleration exposure via instrumented mouthguards (iMG): a validity and feasibility study protocol to inform iMG suitability for the TaCKLE project. BMJ Open Sport Exerc Med 2021;7:e001125. doi:10.1136/bmjsem-2021001125

5 McClelland C, Kinirons M, Geary L. A preliminary study of patient comfort associated with customised mouthguards. Br J Sports Med 1999;33:186-9. doi:10.1136/bjsm.33.3.186

6 Brooke john. SUS: A ‘Quick and Dirty’ Usability Scale. In: Usability Evaluation In Industry. CRC Press 1996.

7 Sauro J, Lewis J. Quantifying the User Experience - 2nd Edition. 2012.https://www.elsevier.com/books/quantifying-the-user-experience/sauro/978-0-12-802308-2 (accessed 27 Dec 2021).

8 Rugby league to run mouthguard pilot. BBC Sport. https://www.bbc.com/sport/rugbyleague/56744102 (accessed 22 Dec 2021).

9 Cobb BR, Zadnik AM, Rowson S. Comparative analysis of helmeted impact response of Hybrid III and National Operating Committee on Standards for Athletic Equipment headforms. Proc Inst Mech Eng Part $P \quad J$ Sports Eng Technol 2016;230:50-60. doi:10.1177/1754337115599133

10 Cobb BR, MacAlister A, Young TJ, et al. Quantitative comparison of Hybrid III and National Operating Committee on Standards for Athletic Equipment headform shape characteristics and implications on football helmet fit. Proc Inst Mech Eng Part P J Sports Eng Technol 2015;229:39_ 46. doi:10.1177/1754337114548245 
43811 Hendricks S, Till K, den Hollander S, et al. Consensus on a video analysis framework of 439 descriptors and definitions by the Rugby Union Video Analysis Consensus group. Br J Sports 440 Med 2020;54:566-72. doi:10.1136/bjsports-2019-101293

441 Liu Y, Domel AG, Yousefsani SA, et al. Correction to: Validation and Comparison of 442 Instrumented Mouthguards for Measuring Head Kinematics and Assessing Brain Deformation in 443 Football Impacts. Ann Biomed Eng 2021;49:1119-20. doi:10.1007/s10439-020-02701-y

44413 Buchheit M, Al Haddad H, Simpson BM, et al. Monitoring accelerations with GPS in 445 football: time to slow down? Int J Sports Physiol Perform 2014;9:442-5. doi:10.1123/ijspp.2013$446 \quad 0187$

44714 King D, Hume P, Gissane C, et al. The Influence of Head Impact Threshold for Reporting 448 Data in Contact and Collision Sports: Systematic Review and Original Data Analysis. Sports Med 449 2016;46:151-69. doi:10.1007/s40279-015-0423-7

45015 Miller LE, Urban JE, Whelan VM, et al. An envelope of linear and rotational head motion 451 during everyday activities. Biomech Model Mechanobiol 2020;19:1003-14. doi:10.1007/s10237452 019-01267-6

45316 Gabler LF, Huddleston SH, Dau NZ, et al. On-Field Performance of an Instrumented 454 Mouthguard for Detecting Head Impacts in American Football. Ann Biomed Eng 2020;48:2599455 612. doi:10.1007/s10439-020-02654-2

45617 Rennie G, Hart B, Dalton-Barron N, et al. Longitudinal changes in Super League match 457 locomotor and event characteristics: A league-wide investigation over three seasons in rugby 458 league. PloS One 2021;16:e0260711. doi:10.1371/journal.pone.0260711 
medRxiv preprint doi: https://doi.org/10.1101/2022.01.28.22270039; this version posted January 30, 2022. The copyright holder for this preprint (which was not certified by peer review) is the author/funder, who has granted medRxiv a license to display the preprint in perpetuity.

All rights reserved. No reuse allowed without permission.

460

461

462

463

464

465

466

467

468

469

470

471

472

473

474

475

476

477

478

479

480

481

482

483

484

485

486

487

Funding: No funding was received to undertake this study.

Competing interests: GT, JT and DW have received Prevent Biometrics iMGs free of charge for use with Leeds Rhinos RLFC, during training and matches for a research project. BJ, MAD, KT are employed by Leeds Rhinos in a consultancy capacity. GT, JT and EF use Prevent Biometrics iMG for research projects funded by World Rugby. EF is employed by World Rugby. BJ, JT, DW, KT, CO, KS, GP, SH, MAD, GT are involved in the Rugby Football League TaCKLE (Tackle and Contact Kinematic Load \& Expsoure) project. BJ and KT will be involved in the procurement of iMGs for the TaCKLE project. BJ, GP are employed in a consultancy capacity by the Rugby Football League. KS is employed by the Rugby Football Union. MB and SR lead the Virginia Tech Helmet Lab. Leeds Rhinos, World Rugby and Virginia Tech are research partners of Prevent Biometrics.

Acknowledgements: The authors would like to thank all players and staff at Hull KR RLFC, Leeds Rhinos RLFC, St Helens RLFC, Wakefield Trinity RLFC, Warrington Wolves RLFC, and Wigan Warriors RLFC for participating in the study. The authors would like to acknowledge the funding (dental scans, project expenses and Virginia Tech lab costs) provided by Leeds Beckett University, Carnegie School of Sport. The authors would like to thank all Super League CEOs, Laura Fairbank and Karen Moorhouse (Rugby Football League) for supporting the project. The authors acknowledge the support of Brianna Mulhern and Mily Spiegelhalter for supporting data collection. The authors would like to thank Dr Anthony Lovat (OPRO) for reviewing dental scans. Finally, the authors would like to acknowledge their sincere gratitude to Dr Nate Dau and Dr Lee Gabler (Biocore [Football Research Inc; FRI]), Damien Hawes and Tom Laudenbach (HitlQ), Robert Paterson and Thomas Quinn (ORB innovations), and Drew Goodger and Dr Adam Bartsch (Prevent Biometrics) for their support and cooperation during the study.

Ethical approval: This project was approved by Leeds Beckett University, Local Ethics Committee (85551). 
Supplementary Table 1. Breakdown of Assumed False-Positives, PPV for Off-Camera Assumed False-Positives, and

\begin{tabular}{|c|c|c|c|c|}
\hline & FRI & HitlQ & Orb & Prevent \\
\hline \multicolumn{5}{|l|}{ False-Positive Guided Analysis } \\
\hline Off-Camera Assumed False-Positives (n) & 5 & 111 & 47 & 34 \\
\hline (mean \pm SD per player, per match) & $(0.3 \pm 0.5)$ & $(4.0 \pm 4.6)$ & $(5.2 \pm 5.0)$ & $(1.3 \pm 2.8)$ \\
\hline False-Positives + Off-Camera Assumed False-Positives (PPV) & 0.95 & 0.64 & 0.38 & 0.89 \\
\hline False-Positives Guided Analysis Total (n) & 4 & 28 & 59 & 45 \\
\hline Inserting, Adjusting, Removing iMG (n (\%)) & $0(0.0 \%)$ & $1(3.6 \%)$ & $39(66.1 \%)$ & $2(4.4 \%)$ \\
\hline Stationary $(\mathrm{n}(\%))$ & $2(50.0 \%)$ & $9(32.1 \%)$ & $6(10.2 \%)$ & $7(15.6 \%)$ \\
\hline Walking (n (\%)) & $0(0.0 \%)$ & $6(21.4 \%)$ & $1(1.7 \%)$ & $1(2.2 \%)$ \\
\hline Running $(\mathrm{n}(\%))$ & $2(50.0 \%)$ & $12(42.9 \%)$ & $13(22.0 \%)$ & $35(77.8 \%)$ \\
\hline \multicolumn{5}{|l|}{ False-Negatives (Unguided Analysis) } \\
\hline False-Negatives $(n)$ & 46 & 73 & 8 & 27 \\
\hline No iMG-triggered event Recorded (n) & 38 & 42 & 8 & 27 \\
\hline iMG-triggered event binned $(n)$ & $8^{*}$ & $31^{*}$ & 0 & 0 \\
\hline \multicolumn{5}{|c|}{$\begin{array}{l}\text { *iMG-triggered events were binned due to iMGs HAE detection algorithms misclassifying iMG-triggered events as false-negatives (FRI } n=8 \\
\text { and HitIQ } n=3 \text { ) and/or because iMG-triggered events' PLA fell below the recording threshold (HitlQ } n=30) \text {. }\end{array}$} \\
\hline \multicolumn{5}{|c|}{$\begin{array}{l}\text { Linear and angular kinematic values are presented in Figure 2, for each iMG vs. reference measurements from Phase 1, and in Figure } \\
3 \text { for true-positive and false-positive iMG-triggered events from Phase } 2 \text {. Supplementary Figure } 2 \text { shows the linear and angular } \\
\text { kinematic values and associated PPV for all false-positives. }\end{array}$} \\
\hline
\end{tabular}




\begin{tabular}{|c|c|c|c|c|c|c|c|c|c|c|}
\hline iMG & $\begin{array}{l}\text { Player } \\
\text { ID }\end{array}$ & $\begin{array}{l}\text { Player } \\
\text { Matches } \\
\text { (n) }\end{array}$ & $\begin{array}{l}\text { True- } \\
\text { Positive } \\
\text { (n) }\end{array}$ & $\begin{array}{l}\text { False- } \\
\text { Positive } \\
\text { (n) }\end{array}$ & $\begin{array}{l}\text { Off-Camera } \\
\text { Assumed } \\
\text { False- } \\
\text { Positives (n) }\end{array}$ & $\begin{array}{l}\text { Inactive } \\
\text { Assumed } \\
\text { False- } \\
\text { Positives (n) }\end{array}$ & $\begin{array}{l}\text { False- } \\
\text { Positive } \\
\text { (PPV) }\end{array}$ & $\begin{array}{l}\text { False- } \\
\text { Positive + } \\
\text { Off-Camera } \\
\text { Assumed } \\
\text { False- } \\
\text { Positives } \\
\text { (PPV) }\end{array}$ & $\begin{array}{l}\text { False- } \\
\text { Positive + } \\
\text { Inactive } \\
\text { Assumed } \\
\text { False- } \\
\text { Positives } \\
\text { (PPV) }\end{array}$ & $\begin{array}{c}\text { False- } \\
\text { Positive + } \\
\text { Off-Camera } \\
\text { Assumed } \\
\text { False- } \\
\text { Positives + } \\
\text { Inactive } \\
\text { Assumed } \\
\text { False- } \\
\text { Positives } \\
\text { (PPV) }\end{array}$ \\
\hline \multirow{11}{*}{$\overline{\bar{\alpha}}$} & $A$ & 1 & 16 & 0 & 0 & 0 & 1.0 & 1.0 & 1.0 & 1.0 \\
\hline & B & 3 & 39 & 0 & 1 & 29 & 1.0 & 1.0 & 0.6 & 0.6 \\
\hline & C & 1 & 10 & 0 & 0 & 0 & 1.0 & 1.0 & 1.0 & 1.0 \\
\hline & D & 1 & 4 & 0 & 0 & 0 & 1.0 & 1.0 & 1.0 & 1.0 \\
\hline & $\mathrm{E}$ & 2 & 20 & 0 & 1 & 0 & 1.0 & 1.0 & 1.0 & 1.0 \\
\hline & $\bar{F}$ & 3 & 18 & 0 & 0 & 0 & 1.0 & 1.0 & 1.0 & 1.0 \\
\hline & G & 1 & 4 & 0 & 0 & 0 & 1.0 & 1.0 & 1.0 & 1.0 \\
\hline & $\mathrm{H}$ & 2 & 18 & 1 & 2 & 0 & 0.9 & 0.9 & 0.9 & 0.9 \\
\hline & 1 & 2 & 29 & 2 & 1 & 1 & 0.9 & 0.9 & 0.9 & 0.9 \\
\hline & $J$ & 1 & 4 & 1 & 0 & 0 & 0.8 & 0.8 & 0.8 & 0.8 \\
\hline & Total & 17 & 162 & 4 & 5 & 30 & $\begin{array}{c}0.97 \\
( \pm 0.06)\end{array}$ & $\begin{array}{c}0.95 \\
( \pm 0.07)\end{array}$ & $\begin{array}{c}0.92 \\
( \pm 0.14)\end{array}$ & $\begin{array}{c}0.91 \\
( \pm 0.14)\end{array}$ \\
\hline \multirow{19}{*}{ 昱 } & $B$ & 1 & 17 & 0 & 3 & 0 & 1.0 & 0.9 & 1.0 & 0.9 \\
\hline & C & 1 & 6 & 2 & 5 & 0 & 0.8 & 0.5 & 0.8 & 0.5 \\
\hline & D & 1 & 3 & 1 & 4 & 0 & 0.8 & 0.4 & 0.8 & 0.4 \\
\hline & E & 1 & 16 & 2 & 1 & 0 & 0.9 & 0.8 & 0.9 & 0.8 \\
\hline & $\bar{F}$ & 2 & 15 & 0 & 9 & 2 & 1.0 & 0.6 & 0.9 & 0.6 \\
\hline & G & 2 & 10 & 1 & 7 & 0 & 0.9 & 0.6 & 0.9 & 0.6 \\
\hline & $\mathrm{H}$ & 2 & 22 & 1 & 10 & 2 & 1.0 & 0.7 & 0.9 & 0.6 \\
\hline & 1 & 2 & 23 & 3 & 14 & 0 & 0.9 & 0.6 & 0.9 & 0.6 \\
\hline & $J$ & 1 & 11 & 0 & 1 & 1 & 1.0 & 0.9 & 0.9 & 0.8 \\
\hline & $\mathrm{K}$ & 1 & 2 & 0 & 4 & 0 & 1.0 & 0.3 & 1.0 & 0.3 \\
\hline & $\mathrm{L}$ & 1 & 19 & 0 & 1 & 0 & 1.0 & 1.0 & 1.0 & 1.0 \\
\hline & $M$ & 2 & 30 & 1 & 2 & 1 & 1.0 & 0.9 & 0.9 & 0.9 \\
\hline & $\mathrm{N}$ & 1 & 2 & 0 & 1 & 1 & 1.0 & 0.7 & 0.7 & 0.5 \\
\hline & 0 & 2 & 13 & 4 & 10 & 1 & 0.8 & 0.5 & 0.7 & 0.5 \\
\hline & $\mathrm{P}$ & 2 & 14 & 6 & 1 & 1 & 0.7 & 0.7 & 0.7 & 0.6 \\
\hline & Q & 2 & 17 & 1 & 2 & 3 & 0.9 & 0.9 & 0.8 & 0.7 \\
\hline & $\mathrm{R}$ & 2 & 7 & 2 & 20 & 0 & 0.8 & 0.2 & 0.8 & 0.2 \\
\hline & $S$ & 2 & 18 & 4 & 16 & 9 & 0.8 & 0.5 & 0.6 & 0.4 \\
\hline & Total & 28 & 245 & 28 & 111 & 21 & $\begin{array}{c}0.90 \\
( \pm 0.11)\end{array}$ & $\begin{array}{c}0.64 \\
( \pm 0.22) \\
\end{array}$ & $\begin{array}{c}0.83 \\
( \pm 0.13)\end{array}$ & $\begin{array}{c}0.60 \\
( \pm 0.21)\end{array}$ \\
\hline \multirow{8}{*}{$\begin{array}{l}m \\
\stackrel{n}{0}\end{array}$} & $T$ & 2 & 35 & 19 & 10 & 7 & 0.6 & 0.5 & 0.6 & 0.5 \\
\hline & U & 1 & 16 & 23 & 13 & 0 & 0.4 & 0.3 & 0.4 & 0.3 \\
\hline & V & 1 & 7 & 3 & 6 & 0 & 0.7 & 0.4 & 0.7 & 0.4 \\
\hline & W & 1 & 7 & 2 & 0 & 0 & 0.8 & 0.8 & 0.8 & 0.8 \\
\hline & $x$ & 1 & 1 & 1 & 4 & 0 & 0.5 & 0.2 & 0.5 & 0.2 \\
\hline & $\hat{Y}$ & 2 & 0 & 7 & 13 & 0 & 0.0 & 0.0 & 0.0 & 0.0 \\
\hline & Z & 1 & 0 & 4 & 1 & 0 & 0.0 & 0.0 & 0.0 & 0.0 \\
\hline & Total & 9 & 66 & 59 & 47 & 7 & $\begin{array}{c}0.43 \\
( \pm 0.32)\end{array}$ & $\begin{array}{c}0.32 \\
( \pm 0.29)\end{array}$ & $\begin{array}{c}0.42 \\
( \pm 0.31)\end{array}$ & $\begin{array}{c}0.31 \\
( \pm 0.28)\end{array}$ \\
\hline \multirow{13}{*}{ 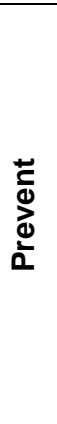 } & $M$ & 3 & 144 & 3 & 1 & 0 & 1.0 & 1.0 & 1.0 & 1.0 \\
\hline & $\mathrm{N}$ & 3 & 93 & 0 & 2 & 0 & 1.0 & 1.0 & 1.0 & 1.0 \\
\hline & $\mathrm{O}$ & 3 & 48 & 7 & 16 & 0 & 0.9 & 0.7 & 0.9 & 0.7 \\
\hline & $\mathrm{S}$ & 3 & 111 & 21 & 9 & 0 & 0.8 & 0.8 & 0.8 & 0.8 \\
\hline & $U$ & 3 & 61 & 2 & 3 & 0 & 1.0 & 0.9 & 1.0 & 0.9 \\
\hline & $\mathrm{V}$ & 3 & 62 & 0 & 0 & 0 & 1.0 & 1.0 & 1.0 & 1.0 \\
\hline & W & 2 & 28 & 3 & 0 & 0 & 0.9 & 0.9 & 0.9 & 0.9 \\
\hline & AA & 1 & 0 & 0 & 1 & 0 & 0.0 & 0.0 & 0.0 & 0.0 \\
\hline & $A B$ & 1 & 7 & 2 & 1 & 0 & 0.8 & 0.7 & 0.8 & 0.7 \\
\hline & $A C$ & 3 & 82 & 6 & 1 & 0 & 0.9 & 0.9 & 0.9 & 0.9 \\
\hline & $A D$ & 1 & 17 & 0 & 0 & 0 & 1.0 & 1.0 & 1.0 & 1.0 \\
\hline & $\mathrm{AE}$ & 1 & 13 & 1 & 0 & 0 & 0.9 & 0.9 & 0.9 & 0.9 \\
\hline & Total & 27 & 666 & 45 & 34 & 0 & $\begin{array}{c}0.85 \\
( \pm 0.28)\end{array}$ & $\begin{array}{c}0.82 \\
( \pm 0.27)\end{array}$ & $\begin{array}{c}0.85 \\
( \pm 0.28)\end{array}$ & $\begin{array}{c}0.82 \\
( \pm 0.27)\end{array}$ \\
\hline
\end{tabular}




\section{Supplementary Table 3. Fit, Comfort and Function for each questionnaire item from} Phase 3.

\begin{tabular}{lcccc}
\hline Question & FRI & HitlQ & Orb & Prevent \\
\hline Fit & & & & \\
(\% of participants who responded 'no') & & & & \\
aToo loose & 95 & 89 & 78 & 94 \\
aToo tight & 84 & 95 & 67 & 83 \\
aToo bulky & 16 & 63 & 22 & 67 \\
aToo small or thin & 100 & 95 & 94 & 100 \\
aHeld your mouth open & 42 & 79 & 39 & 72 \\
aHeld your teeth apart & 89 & 89 & 72 & 89 \\
aCreated pain in your jaw muscles & 95 & 95 & 83 & 94 \\
aCreated an uneven bite & 95 & 100 & 67 & 83 \\
\hline Comfort & & & & \\
(Median [IQR] of responses to a 0-10 likert scale) & & & & \\
bOverall comfort & $6(5,7)$ & $7(6,8)$ & $3(2,5)$ & $7(5,8)$ \\
'Lip comfort & $5(4,6)$ & $7(6,8)$ & $5(3,6)$ & $8(7,8)$ \\
bGum comfort & $6(5,7)$ & $7(6,8)$ & $5(2,6)$ & $7(7,8)$ \\
bTongue comfort & $7(6,8)$ & $8(7,8)$ & $5(3,5)$ & $8(7,8)$ \\
bTooth comfort & $6(6,8)$ & $8(7,9)$ & $5(3,7)$ & $8(5,8)$ \\
bHow well it held in your mouth & $6(6,8)$ & $8(8,9)$ & $5(3,7)$ & $8(7,9)$ \\
'Ease of breathing & $6(5,7)$ & $7(6,8)$ & $5(3,6)$ & $8(6,8)$ \\
\hline Function & & & & \\
(\% of participants who responded 'no', 'a little', 'a lot') & $16,58,26$ & $21,68,11$ & $11,39,50$ & $44,39,17$ \\
'Interferes with speech & $58,42,0$ & $58,42,0$ & $28,44,28$ & $56,44,0$ \\
CInterferes with swallowing & $47,42,11$ & $69,26,5$ & $50,33,17$ & $72,22,6$ \\
'Causes a dry mouth & $100,0,0$ & $95,5,0$ & $83,6,11$ & $94,6,0$ \\
'Causes nausea & 55.3 & 60.8 & 43 & 66.5 \\
Mean 'No' & 35.3 & 35.3 & 30.5 & 27.8 \\
Mean 'A little' & 9.3 & 4.0 & 26.5 & 5.8 \\
Mean 'A lot' & & & \\
\hline
\end{tabular}

${ }^{\mathrm{a}}$ With regards to the fit of the mouthguard, did you feel that this mouthguard was; ${ }^{\mathrm{b}}$ On reflection 


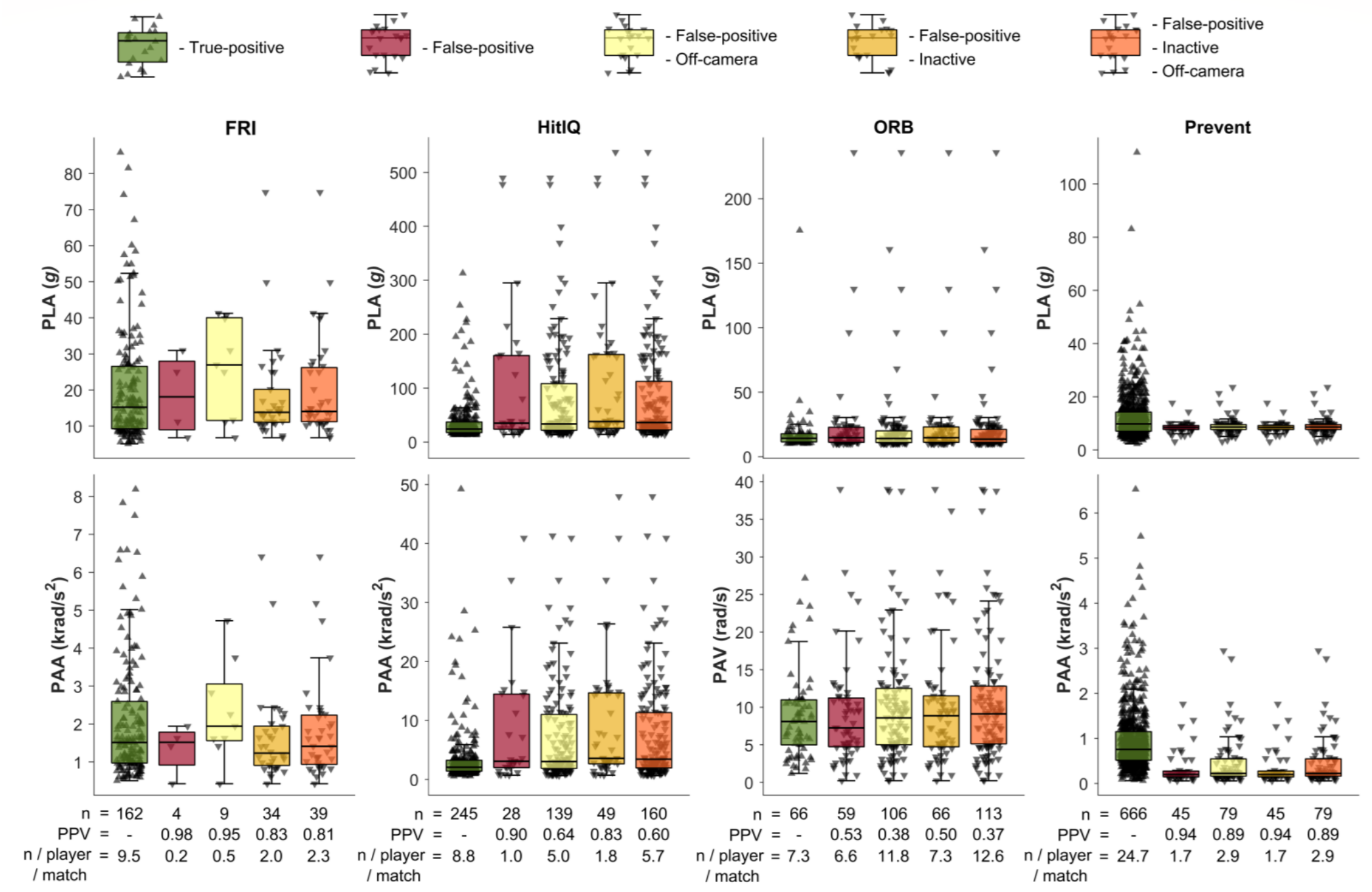

Supplementary Figure 1. Peak linear and angular on-field kinematic values, associated PPVs, number per player, per match of true-positives, false-positives, and combinations of false-positives and assumed false-positives for each iMG from Phase 2. Note. $Y$ axis scale specific to data reported by each iMG. 